\title{
Chancery: The Symbolic Monster and Contageous Disease Affecting Every Facet of Life - A Case of Dickens' Bleak House
}

\author{
Aringo-Bizimaana Peter \\ PhD Candidate at Uganda Christian University (Mukono - UGANDA) \\ A Lecturer at Kabale Public University (Kabale - UGANDA) \\ Corresponding author: Aringo-Bizimaana Peter; apbizimaana@kab.ac.ug
}

Received 12 June 2019;

Accepted 11 August 2019;

Published 22 August 2019

\begin{abstract}
This article first explores the key technique that sets the tone and mood of the whole novel: the symbolic setting. We then explain what is symbolic about the bleakness of London weather and terrain by examining Dickens' thematic disclosure that will comprise examining : the symbolic setting of the novel (London); Chancery as a symbol of individualism, corruption and deception (discussed using corrupt lawyers); Chancery as symbol of incompetence and irresponsibility; Chancery as disease; Chancery as the disease of poverty and disillusionment (breeding class differences and causing family disintegration); and, finally, Chancery as a destroyer of religion.
\end{abstract}

Keywords: Chancery, monster, disease, bleak, smells, 'meaty setting'

\section{Introduction}

As Collin (1994), Hanson (2012) and Nair (2017) observe, Bleak House is at once summarized in the first chapter where the author, business-like, and with a dramatic voice, sets the tone, mood and message of the novel: London is under attack. Weather at once takes on a monstrous personification with incredibly debilitating force, entrapping the citizenry into a quagmire. Nair (2017: 136) calls this visualization of London as Dickens' "Balloon View" and a "bird's eye view", by rising up above the city, so to say, and looking at the horror below from above, like one endowed with a "divine gaze", narrating what "death of the Sun" from fog implies. This is how Dickens can capture the obscurity, illegibility and incomprehensibility of what the city environment has become thereby stretching this state of darkness into the bleakness of physical, social, economic and spiritual bleakness. This bleak London, therefore, being imprisoned in a sea of mud, the atmosphere blanketed in fog and smoke, and only a 'soft black of the sun' showing, becomes the dominant metaphor of the novel. The reader can then visualize how animals and humans are struggling to extricate themselves from this massive bog (BH: 50). The action verbs used ('jostling...waddling...slipping...losing' control) visually and audibly demonstrate frantic attempts to escape. But, like a monstrous hand of a huge beast, the accumulating mud, moreover continually accumulating 'at compound interest' will not allow any escape: it is sticking on every being and incapacitating movement. The voice then spreads this visual image across London streets, factories, homes and the city-hinterland, and even towards the end of the novel, it leads the reader to the North of the country. The reader is prompted to note the allusion to the devastating Biblical Flood engulfing the Land, and to note another very important pointer: this 'implacable November weather' is rawest, densest, muddiest 'near that leadenheaded old obstruction... Temple Bar (where) sits the Lord High Chancellor in his High Court of Chancery'. (BH: 50). Thus, in this juxtaposition, a residual image finally emerges from this foregrounding of the novel, turning the passage into a symbolic setting and representation of Chancery as an institution with a devastating hold on the whole nation, on lives of people stuck in most debilitating conditions (Henchman: 2017; Nair: 2017; Gholami and Joodaki: 2014; Radu: 2016;) et al. It is a condition propagated by a most corrupt assortment of lawyers who connive to make legal justice for their suitors the quagmire symbolically described above. As one reads further into the novel (BH: 603604), one discovers where the gridlock, the thickest and rawest mud is:

The one great principle of the English law is to make business for itself. There is no other principle distinctly, certainly and consistently maintained through all its narrow turnings. Viewed by this light it becomes a coherent scheme and not the monstrous maze the laity are apt to think it. Let them but once clearly perceive that its grand principle is to make business for itself at their expense, and surely they will cease to grumble.

Delving into this symbolic setting of a lurid weather and entrapping terrain presents a very involving mesh of themes and ideas triggered by the symbolized lurid judicial system, the Chancery. We, therefore, suggest unraveling this mesh, the 
workings of this legal system, by examining it under the following headings - Chancery (the judicial system) as

1. A symbol of individualism, corruption and deception;

2. Incompetence and irresponsibility;

3. Many types of disease; and especially,

4. The disease of Poverty and Disillusionment

5. Destroyer of Religion.

\section{Symbol of individualism, corruption and deception}

We want to remark first of all that Dickens intentionally introduces the 'feeding' metaphor of the lawyers we want to examine soon relating them to beasts, animals and cannibals to draw our attention to the typical behavior of Chancery lawyers. The lawyers in the novel have taken on the individualistic nature of many beasts of prey who never share their kills, but ravage with impunity.

\subsection{Vholes}

The characterization of Vholes underscores the beast that hunts unsuspecting Richard to parasite on him till the host is dried up and dead. Dickens' use of nomenclature here is critical because Vholes' name is a mutilation from a vole, which is a field mouse known for devastating field crops and so lives burrowing within the fields to ensure enough food for itself and the offspring. This is exactly the same way Vholes keeps repeating why he must 'toil' to fend for his daughters and ageing father! Dickens' use of Esther as key narrator is a most apt choice as a woman of quiet but immense critical observation. Partly for her humanistic concern for a poor Richard she likes so much and would protect to death, she observes this parasitic Vholes and notes (BH: 591) - "I never shall forget those two (Richard and Vholes) seated side by side... Mr Vholes quite still, black-gloved, and buttoned up, looking at (Richard) as if he were looking at his prey and charming it". It is "his slow fixed way of looking at Richard ... with an inward manner of speaking ..." (BH: 591), in a 'stifled tone', exactly in the manner of a witchdoctor's ventriloquism to mesmerize his victim of fraud. His deceptive refrain is always "We have put our shoulders to the wheel, Mr Carstone, and the wheel is going round... have more patience..." Esther also observes how Vholes keeps looking at his prey 'as if he were making lingering meal of him with his eyes as well as with his professional appetite' and then reiterating he must attend to this prey's interests 'with a cool head' (BH: 607). As he grows confident he has his prey trapped, Vholes begins, but in a cruelly persuasive tongue, to get Richard convinced to pay incredible expenses in form of advances, travel claims, meals et $\mathrm{c}$. He never relaxes looking at him like a 'cat watches the mouse's hole' where the mouse will appear (BH: 608). Ironically indeed, Richard pays 'for the ultimate behoof of (Vhole's) three daughters. So might an industrious fox, or bear, make up his accounts of chickens or stray travelers with an eye to his cubs..." (BH: 610611). At another time, Esther, contemplating Richard's situation with Vholes, has visualized Richard in a frightening symbol of one buried deep into "the dead sea of the Chancery suit and all the ashy fruits it cast ashore" (BH: 592). Even Esther's guardian sees this ghostly Vholes as a "bird of ill-omen" (BH: 671). The reference to death is equally symbolically critical here because, he bears many other frightening epithets: he is always attired in black, with 'funeral gloves' (BH: 672); he has 'gliding' movements like a static, unmovable object flitting through the room in his 'usual ghostly appearance' (BH: 589) and whose 'shadow chills seeds in the ground' (BH: 673). The final image of this creature is of a very frightening symbol of an undertaker: he will soon dispatch Richard into total disillusion and to his death as seen at the end of the novel. Indeed, finally, Esther has seen Vholes as a fearsome 'Vampire' (BH: 876) as she also notices now Richard is a dying thing: 'bent head, bitten nails, the lowering eye, the lingering step, the purposeless and dreamy air, the good in him consumed, the life turned sour. Chancery, which knows no wisdom but in Precedent, is very rich in such Precedents; and why should one be different from ten thousand?'

\subsection{Mr Krook.}

This is Vholes' counterpart - another ghost character (BH: 98-101) - living holed up in his 'RAG AND BOTTLE WAREHOUSE', a shop-cum-rentals, dealing in all manner of trash that include dead women's hair, bags and bags of dusty and embrowned Chancery papers and all types of bottles with all manner of liquids including blacking and wine bottles, ink bottles. He prides in

being in a legal neighborhood (as) a dirty hanger-on and disowned relation of the law (with even) old volumes labeled "Law Books, all at 9d" and dog-eared law papers, a litter of rags, bones in a corner piled together and picked very clean ... (and Ada and Esther thought them) bones of clients, to make the picture complete. (And he is very proud that) they call me the Lord Chancellor, and call my shop Chancery.

To put a finishing touch to this weird heap of possessions, he owns a cat named Lady Jane, a tigerish creature he has taught to rip up who/whatever it and he do not like. It is two predators in a den. To add to his weirdness, and frighteningly ironic, the final picture of the shop-den is of "heaps of rust, must, cobwebs, rack and ruin...". But crucial to him, despite the clutter, he will not sweep or repair anything: it's all fish for his net, and "That's the way I've got the ill name of Chancery... (And also because) I go to see my noble and learned brother pretty well every day, when he sits in the Inn. He don't notice me, but I notice him. There is no great odds betwixt us. We both grub on in the muddle". (BH: 98-101).

Certainly this is another symbolic presentation of predation in the novel, especially when we factor into his scavenging for things and always with his Lady Jane, a fearsome cat trained to rip to pieces, with its 'tiggerish claws' what it (and he) do not like; after all, he deals 'with cat-skins'. No wonder Miss Flite, his tenant, must cage his birds and constantly check on their safety because Lady Jane would eat them up, just like Chancery does to law-suitors.

The juxta-positioning of Krook, the cat and Chancery is of symbolic significance: they are all crooks, predators and cannibals; they all rip up things and Chancery has specialized in ripping off people, stealing their meager savings and inheritance, sending them to an early death or into madness. In fact Krook's visitors (he has known they are connected to the misfortunes of the dead Tom Jarndyce) soon learn about Chancery's ripping practices: it is what happened to their-would-have-been guardian, Tom Jarndyce. Gridley tells them later how Tom was ripped apart and cannibalized -

He got into a restless habit of strolling about when the cause was on, or expected, talking to the little shopkeepers and telling 'em to keep out of Chancery, whatever they did. For... it's being ground to bits in a slow mill; it's being roasted at a slow fire; it's being stung to death by single bees; it's being drowned by drops; it's going mad by grains". And indeed the man shot himself dead to end the torture of waiting for settlement of his case (BH: 102). 


\subsection{MrTulkinghon}

This is a stone-hearted crook; his description betrays the power of a beast gripping its victim with a vicious, suffocating grip. Symbolically, his residence, just like Krook's is a hide-out of

lofty, gusty, and gloomy (atmosphere, with) plenty of dust.. among his furniture and papers... thick everywhere... any wind rushing through his rooms flings as much dust in the eyes of Allegory as the law (and he is always) a hard-grained man, close, dry and silent... impenetrable ( a man full of) mysteries (from countryside to ) shut-up houses in town (and about) himself and his family history, and his money, and his will - all mystery to everyone (BH: 358-59).

George the trooper attests to this power Tulkington has over people, for example himself, just because George has helped Gridley, a wretched victim of Chancery extortion, to settle his small debt. In retribution, this hunter of Gridley, Tulkinghon hits back; George knows this predator is 'able to tumble me out of this place neck and crop (make him homeless, unemployed and a pauper); so he 'keeps me on constant see-saw... (and) he don't see me, he don't hear me... he keeps me prowling and dangling about him - as if I was made of the same stone as himself...' (BH: 699). And this is exactly what he is doing also to the poorest of the poor as revealed by Joe who feels death comes to him as a rescuer from Tulkinghon's hunt for him (BH: 730-35). Tulkinghon's most dangerous tactic is blackmailing his victims as revealed by Lady Dedlock, George and Jo. He is a master of secretive intrigues, insinuating to his victims, therefore, that he knows a lot about their secrets and lives. This psychological torture is felt much more in Lady Dedlock whose life is actually the gripping plot and suspense of the novel: the vicious hunt for her and its debilitating effects on this mother of Esther (narrator and character analyst following up the story of Jarndyce and Jarndyce). Lady Dedlock is an aristocrat by adoption and, therefore, a dangerous liability to the husband, to aristocracy and the royal name of the Dedlocks. She must, therefore, conceal the story of how she was forced to abandon such a beautiful Esther born to a Captain Heydon, but now reduced to only Nemo, a nomenclature symbolic of 'Nothingness', a man without any property, connections of note and repute. But Lady Dedlock still adores this shadow of a man she once loved. So, this worsens her situation among the Dedlocks; she is an imposter and the nomenclature in 'Dedlocks' projects her as being 'locked up' by a cruel past and by Tulkinghon's blackmail. This is not only psychological confinement and torture but also physical both to the body and physical space she cannot now get to utilize and escape from the grip of this parasite. In trying to keep her secret life, the reputation of the husband and family and hide her own past shame, she must accept to suffer quietly. Dickens reduces her to a brooding, bitter and hateful prisoner of a sadist family lawyer. In fact, she is a moving/living ghost. She has symbolically replaced the old ghost of an adulterous wife of the first owner of the Dedlock estates. Rejected by the Dedlocks and bitter, she died cursing the Dedlocks, promising to visit the living Dedlocks unceasingly. That is how her vengeful visits are revealed in the story of an echo that haunts the Ghost Walk at Chesney Wold (BH: $131 \mathrm{ff})$.

We listen to Lady Dedlock's suffocation in the long and tense discussion she and Tulkinghon hold alone where she accuses him of letting part of her secret out to the Dedlocks without taking into account her views and feelings (BH: 626-639). It all sounds like baiting her to err and then he would spill the beans. To worsen the situation, as the family lawyer, he has been given a room in this house and so lives far too near her to avoid. So, hunter-like, he monitors all her movements, employs, Grumpy, Snagby and even Inspector Bucket to complete this hunting motif. Even hunted Jo himself becomes a very important tool when Tulkinghon wants information about letters said to have belonged to Nemo, suspected to be love correspondences between him and Lady Deadlock. And Jo, being a close friend of Nemo for help and food Nemo gives, becomes Tulkinghon's target: the tramp must tell how he came to be connected to Lady Dedlock, to lead her to Nemo's grave, et c.

\section{Therefore, Chancery's Incompetence and irresponsibility}

Just like the stagnant fog and sticky mud imprisoning Londoners, Chancery's method of work is thus annoyingly sadistic and suffocating: lawyers pretending to work on suitors' cases, yet, court sessions turn into much ado about nothing; it is all farce. Watching a typical court session

(S)ome score of members of the High Court of Chancery (are always) mistly engaged in one of the ten thousand stages of an endless cause, tripping one another up on slippery precedents, groping knee-deep in technicalities, running their goat-hair and horsehair warded heads against walls of words and making a pretence of equity with serious faces, as players might...(S)ome solicitors (on a cause) inherited from their fathers, who made a fortune by it... with bills, cross-bills, answers, rejoinders, injunctions, affidavits, issues, references to masters, mountains of costly nonsense, piled before them....all stuck in fog-bank! This is the Court of Chancery (dealing with) decaying houses...worn out lunatic in every madhouse... the dead (suitors), and which gives to moneyed might ...exhausts finances, patience, courage, hope... overthrows the brain and breaks the heart (because) there is not an honorable man among its practitioners who would not give...the warning, "Suffer any wrong that can be done you, rather than come here!” (BH: 50-51)

Dickens, therefore, indicts this system that hypocritically gives hope to suitors and then reverts to deception and blackmail, leaving cases to pile up and rot in the pipeline of clogged 'under consideration'. The feeding metaphor of a deceptive beast in a capitalist system zealously eats up suitors' legacies and inheritances. This is why most of the lawyers are characterized by animal metaphors in their actions or names. Esther, examining the Court in session with the Lord Chancellor seated in great state and gravity tells us...

(Below his) table was a long row of solicitors, with bundles of papers ....at their feet; and then there were the gentlemen of the bar in wigs and gowns - some awake and some asleep, and one talking, and nobody paying much attention to what he said... some of those...present dozed; some read the newspapers; some walked about, or whispered in groups: all seemed perfectly at their ease, by no means in a hurry, very unconcerned, and extremely comfortable. To see everything going on so smoothly, and to think of the toughness of the suitors' lives and deaths; to see all that full dress and ceremony (of lawyers), and to think of the waste, and want, and beggared misery it represented; to consider that, while the sickness of hope deferred was raging in so many hearts, this polite show went on from day to day, and year to year, in such good order and composure; to behold (all these lawyers looking at spectators) as if nobody had ever heard that all over England the name in which these were assembled was a bitter jest; was held in universal horror, contempt, and indignation, was known for 
something so flagrant and bad, that little short of a miracle could bring any good out of it to any one: this was so curious and selfcontradictory to me, who had no experience of it, that it was first incredible, and I could not comprehend it... (BH: 399-400).

But she soon learns this is how the Jarndyce and Jarndyce case has dragged on for ages and how suitors end up maddened like Miss Flite and others commit suicide like Gridley and Tom Jarndyce. Miss Flite's caged birds capture well the symbol of imprisoned suitors, caged into submission because Chancery is a huge prison into which the poor have been incarcerated. The names she gives her birds are indeed very indicative of suitors' high hopes that Chancery gradually drags into total disillusion, despair and even death. Miss Flite's birds, therefore, are real suitors and their fluctuating states of mind and feelings as they desperately wait for justice, in vain. Miss Flite herself is another caged bird. So, as a constant attendant of the court and keen observer of victims of Chancery, patiently waiting and hoping her own case might finally come up for mention and get solved, she has settled to recording the promises and processes of and then deceptions and frustrations from Chancery personified as - Hope, Joy, Youth, Peace, Rest, Life, Dust, Ashes, Waste, Want, Ruin, Despair, Madness, Death, Cunning, Folly, Words, Wigs, Rags, Sheepskin, Plunder, Precedent, Jargon, Gammon, and Spinach..... (BH: 253).

Rags, Sheepskin, Plunder, Precedent, Jargon, Gammon, and Spinach..... (BH: 253).

\section{Chancery as a Disease}

\subsection{The meaty setting and metaphorical air/atmosphere}

Henchman (2017: 1-2) says the setting of this novel is "meaty", with a "greasy atmosphere" surrounded by animal matter suspended in the air that all characters smell, taste and touch. Waters, too, (2011: 4) notices that Dickens often "was well aware of the powerful effect that can reside in objects (like) the handkerchief Esther places on the dead baby of Jenny and eventually ending up in the hands of her desperate mother... (These form) precious objects that tend to bring together the living and the dead". In the introduction to the 1970 edition (p 17) of Bleak House, Hillis Miller himself complements this compactness of style a reader must bear in mind -

The novel must be understood according to correspondences within the text between one character and another, one scene and another one figurative expression and another. If Krook is like the Lord Chancellor, the various Chancery suitors - Miss Flite, Gridley, Tom Jarndyce and Richard - are also alike... so are Tulkinghon, Kenge and Vholes... So that the novel is a complex fabric of recurrences. Characters, scenes, themes and metaphors return in proliferating resemblances...

It is this 'complex fabric of recurrence' that forms the metaphorical presentation of first of all Chancery as a death carrying force because, throughout the novel as we shall see below, it keeps translating into more and more intricately related themes. But, with the meaty setting and the omnipresent smelly air, Chancery turns into a form of animalism, cannibalism unintentionally practiced by unsuspecting characters even outside Chancery as we shall see later concerning, for instance, irresponsible parenthood. This is witnessed in various cases such as the case of Mrs Jellby's sitting room whose air smells of hot tallow from her ever burning candles in tin candlesticks, (and where) candles retain their sheepy atmospheres and release them into surrounding air (to be) consumed"(BH: 476). The room has also a store crammed with assorted things, some undergoing decay, adding to smells in and outside the room. When Nemo is dying, he turns into "an inefficiently burning tallow candle... with a yellow look (so his body is) as a candle wasting away... wasted by poverty, isolation and addiction to opium". In fact the burning smell that he gives off signals his inner deterioration (BH: 188). He was for long diseased, letting off death-smell, before finally succumbing to death within his dingy vault in one of the Rag and Bottle den of rooms.

Then Dickens gives the lawyers their peculiarly obnoxious Chancery odors -

a) Vholes' office is particularly said to smell meaty - "a smell of unwholesome sheep blending with the smell of must and dust (like a daily) consumption of mutton fat in candles and to the fretting of parchment forms and skins in greasy drawers". When he warms himself on a fire on a visit to Bleak House, Esther notices his body steams "diffusing a very unpleasant perfume" (BH: 671-73). He owes this to his 'wolf' characteristics, exactly like such a predator always in bush, stalking prey, drenching itself in the prey's blood as it devours part of the kill and carries the remains to his waiting cubs at home. This is why his daughters are also referred to as 'minor cannibal chiefs' (BH: 671)

b) Krook's body has borne mould of his dingy rentals for long. There is something about his heaps of bags of hair and trash that resonate with Chancery because his practices parody the comical abuse of power by the court: the irresponsible treatment of crucial suitors' documents in very many heavy bags court clerks and messengers carry into the courtroom and before they are done, the so-called court-session ends amidst 'a buzz and a laugh and a general withdrawal of bystanders' (BH: 399-400). This is why Collins (1994: 21-22) thinks it apt to call the Chancery a pestilence indeed because it destroys innocents with its callous irresponsibility. This contagion is further symbolized in the mode of Krook's death. When candle fire sets up an incendiary in his room, his body burns and releases the most disgusting smell. The ashes leave greasy, stinking moisture to the touch and smell, with soot floating in the air, and a "greasy loathsome yellowish liquor, with an unusual stink" smeared on the windows. Krook residues then give off also a smell of tainted and burnt meat with soot that smears 'like black fat'. As Guppy and Weevle come to see him, they smell from far that "smell of burning chops and candles", inhale and even taste the meaty soot particles floating in the hot air before discovering the remains of Krook: greasy ashes. No wonder Weevle feels "greasy (while forcibly smelling and tasting) a queer kind of flavor".

Once more, bad air has united the dead and the living. This is Dickens way of getting readers to notice a pattern of suggestive cannibalism. Henchman (2017) concludes, "Dickens is actively using taboos about food, greasy smells, and meaty tastes to trigger readerly disgust from Jellyby's house, from the the Rag and Bottle Shop of Krook, and from Vhole's office". Gholami and Joodaki (2014) also remark that this disgust evinces a sense of a coherent natural order gone fundamentally awry in the 
modern world of industrial capitalism that has effected immense pollution, poor sanitation and resultant fatal diseases and many deaths. It is these varied layers of disease interpretation that makes the unnamed disease in the novel become a symbol of a vastly diseased society in various forms of corruption/rotting. The contagion spares nobody, not even the apparently invincible Tulkinghon because he is already under attack.

c) He is described as 'a dingy London bird... smoke-dried and faded (and who), in the oven made by the hot pavements and hot buildings... has baked himself drier than usual" as he concentrates on what is going to destroy him: accumulation of riches, corruption $(\mathrm{BH}$ : 698). It is a prophetic message of his coming death as we soon learn how his corpse is almost unapproachable. Dickens hardly gives him any mourners to accompany the hearse, suggesting an avoidance of the stench it is spreading (see this in 3.2 below).

Dickens, therefore, as Hitchman suggests, introduces air as a narrative technique, a metaphor for wider interpretation of carriers of industrial Revolution evils, a figurative metonym for cannibalism, capitalism and individualism. This also, therefore, serves to point out the resultant waste, starvation and pollution involved" (2017: 5). These are, of course, the moral consequences Dickens raises to underscore corruption of the Chancery, a decaying system that kills because it is a disease that attacks every facet of people's lives: physical, mental, spiritual. And Dickens has seen this killing in many "decaying houses...blighted lands in every shire (with their) worn-out lunatics in every madhouse, and its dead in every churchyard..." all over England (BH: 51).

\subsection{Chancery and Metaphors of disease and contagion shared by the rich and the poor}

The observations in 3.1 above, therefore, make Nair (2017: 137) conclude the meaty setting and atmosphere of polluted air point to the pollution of the city from which spring the spread of contagious diseases. The notorious slum, Tom-All-Alone's, the paupers' graveyard, Krook's Rags and Bottle shop and the High Court Chancery are all breeding grounds for disease, contagion and other horrors that run through the novel. Jo becomes a very crucial connection between the high and middle classes' ways of living and those society rejects. Esther's magnanimous heart almost invites death for herself when she ministers to a dying Jo and then catches his contagion. So, the Jos of Tom-All-Alone's may be relegated to the periphery of the city to share existence with the paupers' graveyard and maggots, but they have a lot they share with even the aristocrats, the Dedlocks. In a cruel twist of connections, Lady Dedlock must seek out Jo to help her secretly visit the scene of her lover's grave; she is immensely grateful and magnanimous, which overwhelms Jo. He had never received such rich harvest of alms as a guinea. For Lady Dedlock, the visit gets her fixated with the idea of dying lying on that spot said to be Nemo's grave, and so joins the aristocracy with the graveyard of the destitute. In the end, Chesner Wold (the world of the rich, of gentlemen and ladies, of the bourgeoisie), has merged with the maggots' world in Tom-All-Alone's. Esther sees all this twist of irony and cruel fate as she walks to heaps of dishonored graves and stones, hemmed in by filthy houses, with a few dull lights in the windows, and on whose walls a thick humidity broke out like a disease. And on the step at the gate, drenched in a fearful wet of such a place, which oozed and splashed down everything, I saw, with a cry of pity and horror, a woman lying (there)... I lifted the heavy head, put the long dank hair aside, and turned the face. And it was my mother, cold and dead (BH: 868-87).

Inspector Bucket also sees this ironic proximity - the poor too close to the rich and all diseased without their fully being aware of the contagion - "he mounts a high tower in his mind, and looks out far and wide. Many solitary figures he perceives, creeping through the streets; many solitary figures out on heaths, and roads, and lying under haystacks... as if Bucket takes the place of the omniscient narrator (which) joins in voicing the need for urban social reform" (Nair: 2017-137).

The most mocked and ironic death is certainly that of Tulkinghon, the chief scourge of justice seekers. Dickens uses his death to sound a warning: death knows no rich man. He, therefore, sarcastically narrates -

The amount of inconsolable carriages is immense. The Peerage contributes more four-wheeled affliction than has ever been seen in that splendid neighborhood. Such is the assemblage of armorial bearings on couch panels that the Heralds' College might be supposed to have lost its father and mother at a blow. The Duke of Foodle sends a splendid pile of dust and ashes with silver wheelboxes, patent axles, all the last improvements, and three bereaved worms. Six feet high, holding on behind, in a bunch of woe (BH: 769).

We note the diminution to waste of a paragon of Law that hitherto has held lives in his power. Death here has reduced him to a ridiculous heap of ashes and dust, what with expensive empty carriages contributed by Sir Leicester and his noble House being the ones accompanying the corpse. Human mourners have been excluded from this phony show. This is Dickens' deliberate retention of sympathy for such scourges of humanity whom death reduces to inanimate nonentity, dust, ashes, just like Nemo, Jo, Gridley, Richard, Tom Jarndyce and thousands of others cruel law sends to death out of disease and deprivation. Waters (2011: 18) remarks on how Dickens continually reminds humanity of the absurdity of opulence and meaningless respectability the rich display over the dead relatives, and the whole ridiculous panoply that falsify proper human emotions. It is the way materialism and corruption have completely diseased the hearts of the Tulkinghons and Dedlocks, making them intellectually diseased, incapable of seeing the difference between human beings and things, property and prestige. Dickens, therefore, translates the mud and fog the rich are stuck in as diseased hearts from extreme indulgence in accumulation, a moral disease as symbolized in "the dead Sun" right from the start of the novel. That is the equivalent of the diseases and contagion of the poor from the squalor they live in, from malnutrition and from being totally betrayed and neglected by a legal system and a government that should defend them.

\section{Chancery, therefore, as the disease of poverty and disillusionment}

Dickens' description of slums and sites of impoverishment and squalor is painfully detailed to underscore the wrong done to millions of the underprivileged. Tom-All-Alonne's becomes a superb symbol of endemic poverty, disillusionment and even death. The slum is an eyesore and a heartsore. It is a street of perishing blind houses, with their eyes stoned out; without a pane of glass (or) so much as a window-frame, with the bare blank shutters 
tumbling from their hinges and falling asunder... iron rails peeling away in flakes of rust; the chimneys sinking in, the stone steps to every door (juust as the door) is Death's Door turning stagnant green...decaying... These are the great Seal's impressions... all over England (BH: 251).

And, naturally, no wonder that where the brick-maker lives (BH: 256-58), we find a dead child, gaunt and ill-clothed mothers, starved children and drunken men and women. Drunkenness seems to offer momentary relief from poverty pangs for men and some women. Domestic violence is added to other forms of violence from pent up energies, frustrated existence. No wonder Tom-AllAlone's must be dreaded by the rich, and the Jos must be confined to ferreting in their own quarantined slums of London. In such violent living, such squalor, without portable water, ablution facilities, unprotected from adverse weather, with hardly any sure nourishing meal and hope of meaningful employment, then poverty induced deaths must occur. And Esther and Ada feel this deprivation very deeply when they visit the brickman's residence (BH: 159) - "The children sulked and stared; the family took no notice of us whatsoever... We both felt painfully sensible that between us and these people, there was an iron barrier, which could not be removed..."

Gholami and Joodaki (2014) put this social-economic barrier as a most crucial basis for taking Bleak House seriously as a realist portrayal of political and legal betrayal of the lower classes by a greedy class that took Industrial Revolution to be their chance to subjugate the poor into permanent slavery and deprivation. Looking at Jo and those starved and naked children Esther and Ada see, we, therefore, appreciate the plight Dickens is painting: thousands and thousands of illiterate children born into utter poverty, with no hope of making a meaningful living. This is a reminder of the Oliver Twists and Fegan's school of thieves (Oliver Twist), the Pips and Trap Boys of Great Expectations who can only hope to make it to middle class if the Magwitches are many enough to help. We are seeing the cause and source of child labor the Bounderbys are using (Hard Times). Indeed it is a most serious central problem of 19th Century England. The new class of industrialists (the bourgeoisie) has hijacked the political power through control of the economy and their utilitarian philosophy. Their extreme selfishness and greed have dehumanized not only themselves but those they exploit for more riches in factories and industries. One sees this comment made about Roucewell, George's industrialist-brother as George leads us to the North of the country (BH: 902-04) to behold the fog and pollution from industry chimneys of Roucewell's empire. His "hands (are) sinewy and strong... a little sooty too..." But, on close examination of these workers, examination of the iron and steel accumulation at the factory, of the iron dust on everything and on humans, and of more and more chimneys from "a vaporous Babylon of other chimneys" from competing and increasing industrialists, George helps us see what Dickens is about: the mechanization of humans for economic gain, the loss of human feelings in the embrace of materialism. It is another caption of Coke Town (Hard Times). What George sees is another hub of pollution, disease, poverty and extreme exploitation of even women and children. Here also, the chronic master-slave relationship has taken root. Because he sees something repulsive about "their altered stations" with his brother, he declines working for him and returns to look after an ageing, dying Sir Leicester. He still has some patriotic and humane feelings that make him shy away from adding to the horror he has seen.

\subsection{Extreme poverty juxtaposed against the lavish middle class} and aristocracy

The above caption on Roucewell's empire leads us to view the hurting vastly growing class differences George has shunned. It is a frightening proximity, just as Jo feels terrified at the approach of a desperate Lady Dedlock. Jo has to scuttle away and hide when the rich and legal heavyweights appear because they are a menacing threat to his existence. The poor have lived under the threat of being arrested as criminals. The prejudices of the rich scourges stump the poor with stigma - these ragged tramps are not human; they are a menace to us, to our legal and economic foundation for 'good' living... So, the poor are tolerated to live but precariously, and only when they can be of service to the privileged class. This is the situation Jo finds himself in: bribed generously to give Lady Deadlock information about her dead lover's grave; forcibly made to give information to Tulkinghon and Inspector Bucket about his beloved fellow destitute, Nemo, but for some pittance. Then he must literary disappear from existence, from the neighborhood where other people may use him for vital information reserved only for Chancery. So, like thousands of others like him, Jo must live a hide-and-seek life, hidden from prying eyes of the rich and the legal fraternity. This is the only way he can live to beg and survive since he can no more openly do any sweeping work at the graveyard. As Gholami and Joodaki (2014: 649) put it again, this scum of society is another indictment of the privileged political and economic class. This is why Dickens places Jo's existence near the Chancery -

The moral corruption of Chancery is juxtaposed with the physical decay of the slum (Tom-All-Alone's), a ruinous place... avoided by all decent people... (These) tumbling tenements contain by night, a swarm of misery. As on the ruined human wretch (Jo) vermin appear, so these ruined shelters have bred a crowd of foul existence that crawls in and out of gaps in walls and boards; and coils itself to sleep, in maggot numbers, where the rain drips in; and comes and goes, fetching and carrying fever and sowing more evil in its every footprint than Lord Doodle, and Sir Thomas Doodle, and the Duke of Foodle, and all the fine gentlemen in office, down to Zoodle, shall set right in five hundred years though born expressly to do it... (BH: 270).

But, ironically and forcibly, they share the same air and steamy, meaty setting, forcing home to readers to note the iniquities of Chancery. Chancery and upper classes cannot escape being labeled another type of scum existence of fatter vermin feeding on the poor maggots. The spontaneous combustion of Krook in the novel points to Dickens' wish to get such vermin destroyed through reforms because, as Doherty (2018: 6) observes, the scum, fluid and stench left behind by Krook are found even among the Dedlocks: Dickens insists

The damp atmosphere of Chesney Wold brings out unpleasant flavor, the oaken pulpit breaks out into a cold sweat; and there is a general smell and taste as of ancient Dedlocks in their graves. On Sundays, the little church in the park is mouldy; the oaken pulpit breaks out into a cold sweat; and there is a general smell and taste as of ancient Dedlocks in their graves.

Doherty would wish us to conclude from this that the Deadlocks are interred within the church itself against law and custom because the rich had developed the habit of paying hefty sums to get their rich relatives interred in churches to add to family prestige; which is really an invasion of morals by forcing their 
moral corruption into the Churches, spreading the same moral bankruptcy of the Chancery to all church users. One notices also how Dickens shows the contagious nature of the Dedlocks' smells (BH: $456 \mathrm{ff}$ ) - The damp unpleasant smells seem to attract the dead ancestors to invade the Deadlocks' residence leaving the flavors of their graves and then walk through the mansion all night. Dickens insists that as long as the Dedlocks hanker after privileges of aristocracy, as Sir Leicester constantly whines against 'commoners invading their royal world", then the moral corruption of Chancery and the capitalism of privileged classes will not bring about change to at last save the poor from a condemned life. Indeed aristocracy smells and ancestor flavors are the very evils that produce even parasitic commoners who want to imitate the rich living of the bourgeoisie.

\subsection{Chancery destroying Family life and England's children}

Cromwell (1970), Radu (2016), Gholami and Joodaki (2014) and Waters (2011) unequivocally lay blame on irresponsible leadership and a corrupt legal system for the total neglect of the plight of children and causing family disintegration. Even for parents who should be nurturing their young, a struggle to survive, lack of Medicare and, for some, selfish acquisitive urges of a materialistic nation are blinding them to their parental responsibilities. Cromwell (1970: 105) argues that Bleak House represents England, a community of man in which the "agony and misery" of many has created "the dilemmas and torments of decision, action, conscience and guilt". But, for some parents, sheer selfishness and total lack of parental feelings turn exactly into the similar callousness and irresponsibility of Chancery. Harold Skimpole is a first example. Housing his family in a dilapidated house similar to those in Tom-All-Alone's is a sign of growing indifference to others. Cromwell argues again (Ibid, 105) that "Those who do not behave in a fully responsible way towards those with whom they live will not do so towards those with whom they do not live...(This is the same for) the Smallweeds (who) prey upon those who are not Smallweeds but they are quick to turn upon each other".

One sees, therefore, this irresponsible trend getting people to marry without adequate preparation for raising a family. Richard could be excused for being one of them, but still his childish disregard of warnings and advice from their guardian, from the loving Esther and even from Ada he intends to marry and who loves him too deeply must be questioned against a background of unruly and illiterate youths whose home education is totally lacking. Chancery is behind this apparent 'un-thinkingness' of the poor. After all, Richard, too, is an orphan, and it seems a trend that he can't escape living and liking the dilapidated living conditions in the barracks and then rush into marriage to transfer and live in worse housing conditions in Symonds Inn (BH: $610 \mathrm{ff}$ ). The dry rot, dirt, decay and dismal state of an unfinished house symbolize his own lack of maturity. Worse still, as if a pattern of parentless children must also beget orphans, he dies and leaves widow Ada (an orphan, too) with another orphan. Esther's upbringing shares a lot with that of Caddy and her siblings, with that of Prince Turveydrop, George, the Jellyby children, the Pardiggle children, the Skimpole children, et c. So, it seems true what Cromwell has concluded (1970: 107ff) - neglected children are as good as orphans because the whole foundation of the Victorian society, with its incongruous relationships, lack of unsuitability of mind and purpose and the low sense of moral obligations, has turned into the degeneracy of the Chancery. For, a society where crudely selfish and greedy parents such as Skimpole and Turveydrop plan to exploit their own poor children instead of propping them up into some meaningful, family-building practices, then we see how a corrupt and irresponsible leadership from top multiplies production of the Vholes, the Krooks and the Tulkinghons, and then also those in the category of Prince, Caddy, Jo, Richard, et c.

\section{Chancery has destroyed confidence in and roles of Churches to Society}

Cromwell (1970: 123) once more sees how the whole of England is infected "by the condition of decay represented by the rotting corpses of Tom-All-Alone's", its image and that of the odious smells employed in the novel. Tupan (2012: 15-16) sees England, too, as a nation that has lost the moral direction which can only be sustained by having a humane national culture outside the selfish, decadent pride in aristocratic and capitalistic supremacy. Dickens refuses to credit Religion with its traditional role of moral parent because its representatives in Bleak House are another example of leeches and hypocrites society is producing. Such contradictions, as Cooper: 2012; Mason: 2016; van der Veer: 1995; and Akos: 2000 point out, had a tremendous effect on people's beliefs and practices that turned morality into a multi-pronged falsification and misinterpretation of true Faith in a religion. For instance, Kopaszne Lang (2015: 2-3) enumerates quite a number of practices that detracted greatly from convincing moral decency: prudery of the rich and aristocrats, hypocrisy, tolerance of prostitution and homosexuality, enjoyment of pornography on the sly, rampant alcoholism, broken families and child neglect, et c. The depiction of Rev Chadband in Bleak House, for example, displays a savage, totally devoid of Christian feelings. His approach to the problem of Joe (BH: $410 \mathrm{ff}$ ) depicts him as a follower of rulers who believe in theocracy, propping up crude laws of government with equally crude ones of the church to govern people. He has taken a stand with Tulkinghon, a nosy Snagby and the thorough Inspector Bucket to hound Jo out of his usual haunts where he is used to scavenging for survival. He depicts no sense of parental-priestly regard for the destitute. With nauseating mock-piety and concern, he declares his ability to cure Joe of devilish afflictions that have turned him into an irreligious and criminal trump. You cannot give what you do not have: if he has fallen too short of good religious practices, then society and individuals will profit nothing from him. Dickinson (2018: 355) takes up the description Dickens gives Chadband ("yellow skin" which seems to leak "train oil") as one with an appearance of a rotting corpse, like the decaying body of the church in the Dedlocks' ancestral home. Indeed, even to Joe, Chadband is dead to him. This is why he declares to George and Woodward (BH: 704-05) as he is dying -

Mr Chadbands he wos a-prayin wunst at Mr Sangsby and I heerd him, but he sounded as if he wos a-speakin' to himself, and not to me. He prayed a lot, but I couldn't make out nothink on it. Different times there was other gentlemen come down Tom-AllAlone's a-prayin, but they all mostly sounded to be a-talking to themselves, or a-passing blame on the t'others, and not a-talking to us. We never knowd nothink. I never knowd what was all about.

Detached from the horrific realities of the poor within their society, and instead attracted to the common disease of an acquisitive and monetary culture, the Chadbands are no better than the bourgeoisie parasites. One recalls the callousness of Rev Brocklehurst In Jane Eyre, terrorizing a defenseless orphan, Jane, with a meaningless litany of 'principles of good children's behavior', and later preaching to starved, ill-clothed and sickly children while his own live a scandalously luxurious life from money that should be 
looking after orphans at Lowood. He definitely is the typhus that decimates hundreds of these children. This is a replica of the hypocritical man of god seen in the character of the Beadle in Oliver Twist: shameless parasites on donations to orphans in charity homes. This is why Dickens ridicules the "Telescopic Philanthropy of Mrs Jellyby: she has ruined the lives of her own children with the most un-motherly treatment, yet she pretends to be the Good Samaritan on a mission to care for unknown inhabitants of an unknown African country, Borrioboola-Gba. There is an ironic twist in the use of this incomprehensible adacadabra appellation of this nation and the same incomprehensible practices of her philanthropy. The same ridicule goes to Mrs Pardiggle's mock-piety and excessive display of repudiated charity: she is totally incapable of comprehending why her own children hate her and her despicable display of 'good works', Unfortunately, she still will parade the kids before the shocked wards of John Jarndyce and even take them on rounds of 'visiting the wretched' but cannot treat her own children's wretchedness. No wonder that Tom-All- Alone's residents reject such sham preachers, so-called do-gooders.

\section{References}

1. Bakhsh and Hossein Joodaki (2014). "A Social Study of Poverty in Charles Dickens' Hard Times, Bleak House and Oliver Twist”. JNAS Journal. ISSN $2322-5139$.

2. Collins, P. (1994). Dickens and Crime. Pelgrade. Macmillan.

3. Cooper, J., (2012). "What role does religion play in Romantic period writing?" Innavate. Leading Undergraduate Work in English Studies. Volume 4: 2011-2012. Pp 126-32.

4. Cromwell, A. F., (1968). The House, the Family and Domesticity as Central Images in Dickens' Novels. Master's Thesis. University of British Columbia.
5. Doherty, Ruth. (2016). " 'Blest' or 't'thered': Alternative Graveyards in Bleak House, Reynolds and Walker". Victoriographies - A Journal of Nineteenth Century Writing. Volume 8, Issue 3.

6. Hanson, J., (2012). "Presentment, Contrast and Ambiguity in Fictional Space". The Journal of Space Syntax. Vol. 3, Issue: 1.

7. Henchman, A. (2017). "Tallow Candles and Meaty Air in Bleak House". Interdisciplinary Studies in the Long Nineteenth Century.

8. Kopaszne' La'ng, V., (2015). “'Close Your Eyes and Think of England'. Ethics or Prudery: Moral Questions in Victorian England". Tudomanyos segedmunkatarrs Miskolet Egyetem. DOI: 10.26649/music. 2015.101

9. Krassoy Akos. (2002). "Ethics in Dickens - a Case Study (Neo-Pragmatism as a Source of Ethical Criticism in Dickens' Bleak House)”. Modern Filologial Kozilemynyek. IV. Evfoliyam, 2 szam.

10. Mason, E. (2016). "Religion, the bible and literature in the Victorian age". In: John, Juliet, (eds.) The Handbook of Victorian Literary Culture. Oxford; New York: OUP.

11. Nair, R. R., (2017). "The Aesthetics of Balloon View in Bleak House". Rupkhata Journal of Interdisciplinary Studies in Humanities. (ISSN 0975-2935). Vol. ix, No. 2.

12. Radu, L. A., (2016). 'The theme of alienation in "Bartleyby, the Scrivener and Bleak House'. 30 Point Master Thesis. University of Oslo.

13. Tupan, M. A., (2012). "Le Chevalier C. Auguste Dupin and Mr Bucket: Mid-Nineteeth-Century Intimations of the Thought-Police". Rupkathat Journal of Interdisciplinary Studies in Humanities. Vol. 1V, No. 1.

14. Van der Veer, P. (1995). "The Secular Production of Religion”. ETNOFOOR. VIII (2), pp 5-12.

15. Waters, C., (2011). Materializing Mourning: Dickens, Funerals and Epitaphs". Interdisciplinary Studies in the Long Nineteenth Century (14). Pp. 1-20. 